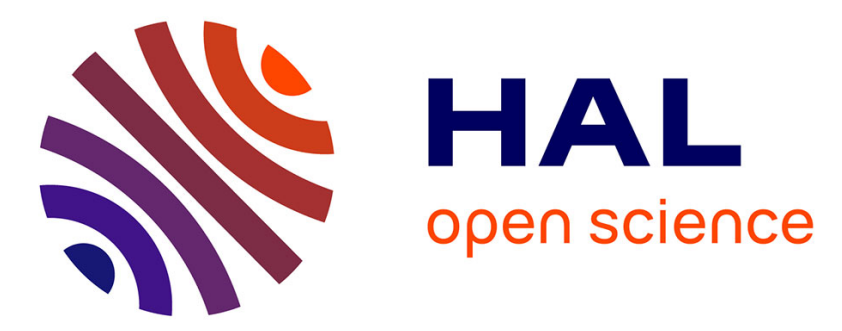

\title{
A reappraisal of hydrocarbons generation and destruction in the petroleum systems of Southern Aquitaine (France)
}

Raymond Michels, Dimitrios Rallakis, Alexy Elias-Bahnan, Guillaume Barre, J. Jacques Pironon, Sylvain Calassou, Eric C. Gaucher

\section{To cite this version:}

Raymond Michels, Dimitrios Rallakis, Alexy Elias-Bahnan, Guillaume Barre, J. Jacques Pironon, et al.. A reappraisal of hydrocarbons generation and destruction in the petroleum systems of Southern Aquitaine (France). 30th International meeting on Organic Geochemistry - IMOG 2021, Sep 2021, Online, France. hal-03429141

\section{HAL Id: hal-03429141 \\ https://hal.science/hal-03429141}

Submitted on 15 Nov 2021

HAL is a multi-disciplinary open access archive for the deposit and dissemination of scientific research documents, whether they are published or not. The documents may come from teaching and research institutions in France or abroad, or from public or private research centers.
L'archive ouverte pluridisciplinaire HAL, est destinée au dépôt et à la diffusion de documents scientifiques de niveau recherche, publiés ou non, émanant des établissements d'enseignement et de recherche français ou étrangers, des laboratoires publics ou privés. 


\section{A REAPPRAISAL OF HYDROCARBONS GENERATION AND DESTRUCTION IN THE}

\section{PETROLEUM SYSTEMS OF SOUTHERN AQUITAINE (FRANCE).}

Michels R. ${ }^{1}$, Rallakis D. ${ }^{1}$, Elias-Bahnan A. ${ }^{1}$, Barré G. ${ }^{2,3}$, Pironon J. ${ }^{1}$, Calassou S. ${ }^{3}$, Gaucher E. C. ${ }^{3}$

1 Université de Lorraine, CNRS, CREGU, GeoRessources lab, UMR7359, 54500

Vandœuvre-lès-Nancy, France

2 Université de Pau et des Pays de 1'Adour, E2S UPPA, CNRS, TOTAL, LFCR, UMR5150, 64000 Pau, France

${ }^{3}$ Total SA, CSTJF, Avenue Larribau, 64000 Pau, France

\section{Introduction}

Sedimentary basins in compressive settings have often complex geological histories and features. Therefore, they present a real challenge in oil and gas exploration. Recent revision of the geodynamic evolution of the North Pyrenees mountain range (France) lead to consider the effects of intense heat flow during the rifting phase prior to compression. We investigated the consequences of this previously unrecognized heating episode on the evolution of the fluids within the petroleum systems on the southern rim of the north Pyrenean foreland basin (Aquitaine basin, France). Results permit to reconsider the maturation history of source rocks, conditions and impact of TSR, secondary migration and reservoir filling as well as to understand the distribution of gas vs petroleum and sourness of fields.

\section{Geological settings}

The Aquitaine basin with $35000 \mathrm{~km}^{2}$ is one of the largest sedimentary basins of Western Europe. It is located in South Western France and subdivided into six geological provinces which lead to major petroleum discoveries. On the most southern rim, at the limit with the North Pyrenean Front, the Adour, Arzacq and Comminges sub-basins contain petroleum systems of major importance: the giant Lacq hydrocarbons field (with the Upper Lacq oil and the Lower Lacq sour gas -18 vol\% $\mathrm{H}_{2} \mathrm{~S}$ - bearing reservoirs), the sour gas reservoirs of St Faust, Cassourat (with $6 \mathrm{vol} \% \mathrm{H}_{2} \mathrm{~S}$ ), the dry gas fields of Meillon, Ucha-Lacommande, Rousse (with $\left.\mathrm{H}_{2} \mathrm{~S}<1 \%\right)$.

Resting on a Palaeozoic basement influenced by an inherited Hercynian tectonic framework, the sedimentary filling of the sub-basins ranges from Triassic to Quaternary. Major events include: thick evaporites deposits during Triassic, the formation of a carbonate platform with source-rocks during Jurassic, a major aborted rifting stage during lower Cretaceous with an hyperextension and mantle exhumation bellow a dragged pre-rift cover and a synrift thickening of rifted basins. This mantle exhumation implied intense heating. Then followed thermal subsidence allowing the deposition of the Cretaceous carbonate platforms (with source-rock), the starting of convergence from upper Cretaceous leading to maximum compression during Paleocene responsible for flysch and then molasses deposits. Then from 20Ma to present, the whole system evolved in a post Orogenic situation with vertical motions due to isostatic rebound of the thicken orogenic crust.

\section{Results}


Taking into account the geodynamic frame, fluids geochemistry was investigated using fluid inclusions from major reservoirs, reservoir gas and oils geochemistry, maturation of the sourcerocks through basin modelling and artificial maturation, multiple sulfur isotopes analysis.

The ultra-thinning of the Earth crust during the aborted rifting stage leads to very intense heating of the major source-rocks of Kimmeridgian and Barremian age along the southern rim of the Aquitaine basin. Maturation modelling indicates that the oil window stage was very brief while source-rocks experienced mostly dry gas generation during Cretaceous. Study of the paleofluids trapped within fluid inclusions of the Deep Lacq reservoir indicates a first filling stage with light oil during Cretaceous. At the beginning of Tertiary during maximal compression stage, rapid evolution to dry gas saturation (+ up to $20 \mathrm{vol} \% \mathrm{H}_{2} \mathrm{~S}$ ) is achieved.

$\mathrm{H}_{2} \mathrm{~S}$ contents (up to 20 vol\% in Deep Lacq) are attributed to TSR. Yet, reservoir rock petrography and fluid inclusions indicate that TSR did not occur within reservoirs while multiple sulfur isotopes investigations on $\mathrm{H}_{2} \mathrm{~S}$ indicate a fully complete reaction (consumption of all available sulfate). Dry gas generation and TSR must have happened in the petroleum kitchen prior to gas migration. Yet, such conditions are not compatible with the evolution of the source-rock/reservoir system where Deep Lacq is located, leading us to conclude that the petroleum kitchen is positioned deeper in the Arzacq basin.

\section{Conclusions}

Advances in the understanding of the structural evolution of the Pyrenees and its impact on the structural and thermal evolution of the southern Aquitaine basin, together with new geochemical investigations lead to revise the history of the petroleum system, especially the identification of a very late dry sour gas filling of the Deep Lacq structure. The consequences on the timing and conditions of TSR, hydrocarbons destruction as well as on gas migration will be discussed.

\section{References}

Clerc, C., \& Lagabrielle, Y. (2014). Thermal control on the modes of crustal thinning leading to mantle exhumation: Insights from the Cretaceous Pyrenean hot paleomargins. Tectonics, 33(7), pp. 1340-1359

Elias Bahnan A., Carpentier C., Pironon J., Ford M., Ducoux M., Barré G., Mangenot X. and Gaucher E. C. (2020) Impact of geodynamics on fluid circulation and diagenesis of carbonate reservoirs in a foreland basin: Example of the Upper Lacq reservoir (Aquitaine basin, SW France). Marine and Petroleum Geology 111, 676-694.

Hart, N. R., Stockli, D. F., Lavier, L. L., and Hayman, N. W. (2017). Thermal evolution of a hyperextended rift basin, Mauléon Basin, Western Pyrenees. Tectonics, 36(6), 1103-1128.

Lagabrielle, Y., Clerc, C., Vauchez, A., Lahfid, A., Labaume, P., Azambre, B., ... \& Dautria, J. M. (2016). Very high geothermal gradient during mantle exhumation recorded in mylonitic marbles and carbonate breccias from a Mesozoic Pyrenean palaeomargin (Lherz area, North Pyrenean Zone, France). Comptes Rendus Géoscience, 348(3-4), 290-300.

Motte G., Hoareau G., Callot J.-P., Révillon S., Piccoli F., Calassou S. and Gaucher E. C. (2021) Rift and salt-related multi-phase dolomitization: example from the northwestern Pyrenees. Marine and Petroleum Geology, 104932.

Renard S., Pironon J., Sterpenich J., Carpentier C., Lescanne M. and Gaucher E. C. (2019) Diagenesis in Mesozoic carbonate rocks in the North Pyrénées (France) from mineralogy and fluid inclusion analysis: Example of Rousse reservoir and caprock. Chemical Geology 508, 3046. 